\title{
Analysis and Design of Prestressed Box Girder Bridge by IRC: 112-2011
}

\author{
Phani Kumar.Ch \\ Student of final year M.Tech Structural Engineering, \\ Mandava Institute of Engineering and Technology, Andhra Pradesh \\ S.V.V.K.Babu, M.Tech \\ Assistant Profeessor, Civil Engg. Department, \\ Sri Vasavi Institute of Engineering and Technology, Andhra Pradesh

\section{D.Aditya Sai Ram, M.Tech} \\ Assistant Professor, Civil Engg. Department, \\ Mandava Institute of Engineering and Technology, Andhra Pradesh
}

\begin{abstract}
Bridge construction today has achieved a worldwide level of importance. Bridges are the key elements in any road network and use of prestress girder type bridges gaining popularity in bridge engineering fraternity because of its better stability, serviceability, economy, aesthetic appearance and structural efficiency. In this thesis analysis and design of prestressed concrete bridges (Deck Slab, T-Girder and Box Girder) are carried out using IRC:112-2011. The unified concrete code (IRC:112) published by the Indian Road Congress in November 2011 combining the code for reinforced concrete and prestressed concrete structures represents $a$ new generation code, which is significantly different as compared to previous codes (i.e. IRC:21 for RCC structures and IRC:18 for PSC structures). IRC:21 and IRC:18 stands withdrawn, with the publication of IRC:112. The fundamental difference between IRC:112 and old codes is that IRC:112 based on limit state theory while the previous codes were based on working stress design philosophy.
\end{abstract}

Keywords: prestress, Deck slab, T-slab, Box Girder, IRC:112.

\section{INTRODUCTION}

Bridges are defined as structures which are provided a passage over a gap without closing way beneath. They may be needed for a passage of railway, roadway, footpath and even for carriage of fluid, bridge site should be so chosen that it gives maximum commercial and social benefits, efficiency, effectiveness and equality. Bridges are nation's lifelines and backbones in the event of war. Bridges symbolize ideals and aspirations of humanity. They span barriers that divide, bring people, communities and nations into closer proximity. They shorten distances, speed transportation and facilitate commerce. Bridges are symbols of humanity's heroic struggle towards mastery of forces of nature and these are silent monuments of mankind's indomitable will to attain it. Bridge construction constitutes an importance element in communication and is an important factor in progress of civilization, bridges stand as tributes to the work of civil engineers.

\section{Classification of Bridges:}

Bridges are classified based on different criteria as follows

- According to function as aqueduct (canal over a river), viaduct (road or railways valley, pedestrian, highway, railway, road-cum-rail or pipe line bridge.

- According to material of construction of super structure as timber, masonry, iron, steel, reinforced concrete, prestress concrete, composite or aluminum bridge.

- According to form or type of super structure as slab, beam, truss, arch, suspension bridge.

- According to inter span relation as simple, continuous and cantilever bridge.

- According to position of bridge floor relative to superstructure as a deck, trough, half-trough or suspension bridge.

- According to span length as culvert (less than $8 \mathrm{~m}$ ), minor bridge ( $8 \mathrm{~m}$ to $30 \mathrm{~m}$ ) or long span bridge. 


\section{Basic Concept of Prestressing}

Prestressing is the application of an initial load on a structure, to enable it to counteract the stresses arising from subsequent loads during its service period. prestressing has been practiced from ancient times the behaviour of spokes of the bicycle when it is loaded, is also example of prestressing. Prestressed concrete is basically a concrete in which internal stresses of a suitable magnitude and distribution are introduced so that the stresses resulting from external loads are counteracted to desired degree. In reinforced concrete members, the prestress is commonly the steel reinforcement.

The minimum grade of concrete in prestressing technique is M40 for pre tensioning and M35 for post tensioning. The tensile strength of concrete is only $8-14 \%$ of its compressive strength of concrete.

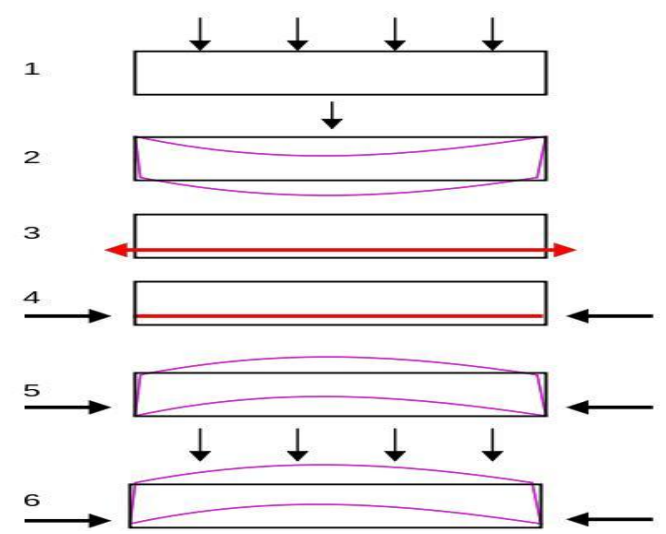

Fig1.1. Behavior of RC member with and without prestressing

\section{Types of Prestress Girders and its Purposes:}

One of the most commonly used forms of superstructure in concrete bridges is precast girders with cast-in-situ slab. This type of superstructure is generally used for spans between 20 to $40 \mathrm{~m}$. Majority of prestress concrete bridges, constructed in India are post tension type. The span to depth ratio is usually kept as 20 for simply supported spans and 25 for continuous spans. The girder spacing of 2 to $3 \mathrm{~m}$. The deck slab overhang should be provided as required to provide the desirable aesthetic effect and to reduce transfer moments. Different types of girder bridges as shown in Figure 2.1

a. Cross section of T-Girder with cast in situ deck

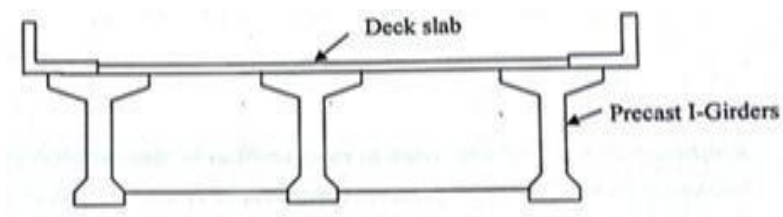

b. I-Girder with cast in situ deck

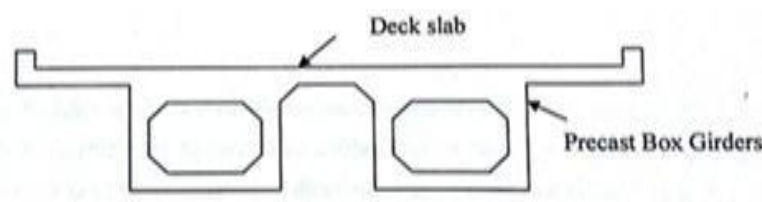

c. Box girder with cast in situ deck

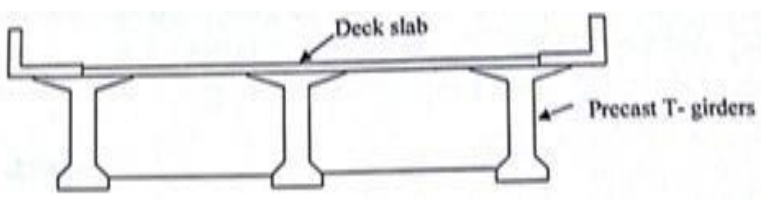

Fig2.1. Different types of girder sections

\section{Finite Element Method}

The finite element method is a technique for analyzing complicated structure by nationality cutting up the continuum of the prototype into a number of small elements which are connected at discrete joints called nodes. For each element, approximate stiffness equation are derived relating the displacements 
of the nodes to the node forces between elements and, in the same way that slope defection equations can be solved for joints in a continuous beam, an electronic computer is used to solved the very large number of simultaneous equations that relate node forces and displacements.

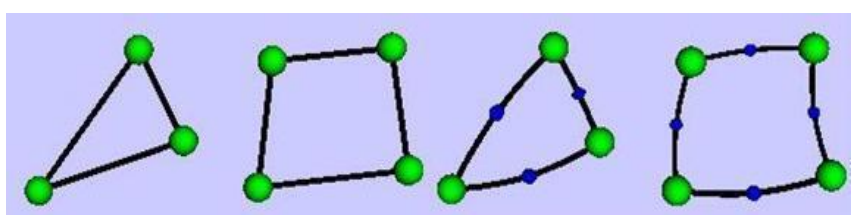

a) 3 Noded Triangle, 4 Noded Quadrilateral, 6 Noded Triangle, 8 Noded Quadrilateral

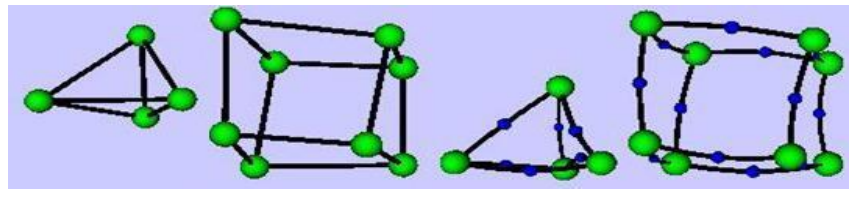

b) 9 Noded Hexahedron, 10 Noded tetrahedron, 20 Noded Curved solid

\section{IRC RECOMMENDATIONS ON DESIGN OF BRIDGES}

The first and major step in any bridge analysis is selection of type of loading, they are dead load, live load, impact effect, wind load, longitudinal force due to tractive effort of vehicles, longitudinal force due to braking of vehicle, seismic effects, earth pressure, vehicle collision forces etc. Out of these loads live load plays a major role.

\section{Vehicle Live Loads:}

Vehicle live loads are categorized based on their configuration and intensity as IRC Class 70R, IRC Class AA (tracked and wheeled type), IRC Class A and IRC Class B loading.

\section{Load Combinations:}

All critical loading stages shall be investigated. The stages stated below

- At the stage of prestressing

- construction stages including temporary loading, transport, handling and erection or any occasional loads that may occur during launching of girders

- design loads according to IRC:6 that includes service dead load, prestress with full losses and service dead load, live load and prestress with full losses

- For the combination of loads with differential temperature gradient effects, maximum 50 per cent live load shall be considered

- Ultimate strength: A prestressed concrete members checked for failure conditions at an ultimate load of

a.1.25 G + 2 SG + 2.5 Q---under moderate conditions

b.1.5 G + $2 \mathrm{SG}+2.5 \mathrm{Q}---$ under severe exposure conditions.

- For sections, where the dead load causes effects opposite to those of live loads shall be checked for $\mathrm{G}+\mathrm{SG}+2.5 \mathrm{Q}$.

\section{Calculation of Ultimate Strength:}

There are two conditions of failure at which strength should be calculated and minimum of these shall be considered for design. They are

a) Failure by yield of steel

$$
\mathrm{M}_{\mathrm{ult}}=0.9 \mathrm{~d}_{\mathrm{b}} \mathrm{A}_{\mathrm{s}} \mathrm{f}_{\mathrm{p}}
$$

b) Failure by crushing of concrete

$\mathrm{M}_{\mathrm{ult}}=0.176 \mathrm{~b} \mathrm{~d}_{\mathrm{b}}^{2} \mathrm{f}_{\mathrm{ck}}$ 


\section{ANALYSIS OF BOX GIRDER BRIDGES}

The methods for the analysis of box girder bridges are as follows

- Simple line analysis or beam analysis

- Grillage analysis

- BEF Analysis (Beams on elastic foundation)

- Space frame analysis

- Finite element method

For study of box girder bridges finite element method is more accurate method.

\subsection{Description of Model}

\section{Loading on Box Girder Bridge:}

The various type of loads, forces and stresses to be considered in the analysis and design of the various components of the bridges are given in IRC 6.

\section{Thickness of Web:}

The thickness of the web shall not be less than $d / 36$ plus twice the clear cover to the reinforcement plus diameter of the duct hole where' $d$ ' is the overall depth of the box girder measured from the top of the deck slab to the bottom of the soffit or $200 \mathrm{~mm}$ plus the diameter of duct holes, whichever is greater.

\section{Thickness of Bottom Flange:}

The thickness of the bottom flange of box girder shall be not less than $1 / 20$ th of the clear web spacing at the junction with bottom flange or $200 \mathrm{~mm}$ whichever is more.

\section{Thickness of Top Flange:}

The minimum thickness of the deck slab including that at cantilever tips be $200 \mathrm{~mm}$. For top and bottom flange having prestressing cables, the thickness of such flange shall not be less than $150 \mathrm{~mm}$ plus diameter of duct hole.

\section{Losses in Prestress:}

While assessing the stresses in concrete and steel during tensioning operations and later in service, due regard shall be paid to all losses and variations in stress resulting from creep of concrete, shrinkage of concrete, relaxation of steel, the shortening (elastic deformation) of concrete at transfer, and friction and slip of anchorage.

\section{Calculation of Ultimate Strength:}

Ultimate moment resistance of sections, under these two alternative conditions of failure shall be calculated by the following formulae and the smaller of the two values shall be taken as the ultimate moment of resistance for design.

Failure by Yield of Steel

$\mathrm{M}_{\text {ult }}=0.9 \mathrm{~d}_{\mathrm{b}}$ As $\mathrm{F}_{\mathrm{p}}$

Failure by Crushing of Concrete

$\mathrm{M}_{\mathrm{ult}}=0.176 \mathrm{~b} \mathrm{~d}_{\mathrm{b}}^{2} \mathrm{f}_{\mathrm{ck}}$

\section{Analysis and Design of Post Tensioned DeCK TyPe Box GiRder BRIDGe}

A post tensioned deck type box girder bridge of clear span $30 \mathrm{~m}$ and width of roadway is $7.5 \mathrm{~m}$ is considered for the analysis. Live loads are taken as per IRC:6. Cross section of box girder is shown in Figure 6.1 and mathematical modeling is done using SAP2000 and is shown in Figure 5.3. The overhang face of the girder is $1.2 \mathrm{~m}$ and deck slab thickness is $0.25 \mathrm{~m}$. Bottom slab thickness is 0.25 $\mathrm{m}$ and girder thickness is $0.35 \mathrm{~m}$. Material properties used are M50 grade of concrete and Fe 415 grade steel. The tendon profile considered is parabolic in nature. The Bridge analysis for different span to depth ratios (L/d) ratio starting from 15 to 19 and different span to depth ratios (L/d) are considered as follows. 
Case1 $\mathrm{L} / \mathrm{d}=15, \mathrm{~d}=2.0$

Case2 $\mathrm{L} / \mathrm{d}=16, \mathrm{~d}=1.9$

Case3 $\mathrm{L} / \mathrm{d}=17, \mathrm{~d}=1.8$

Case4 $\mathrm{L} / \mathrm{d}=18, \mathrm{~d}=1.7$

Case5 $\mathrm{L} / \mathrm{d}=19, \mathrm{~d}=1.6$

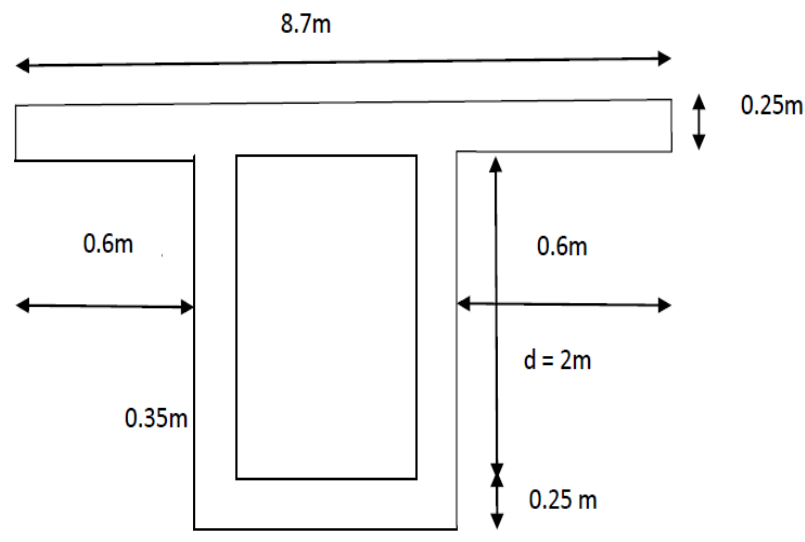

6.1Cross Section of Box-Girder

\subsection{Mathematical Modeling}

The mathematical model of a box girder bridge having a span of $30 \mathrm{~m}$ is shown in Figure6.2

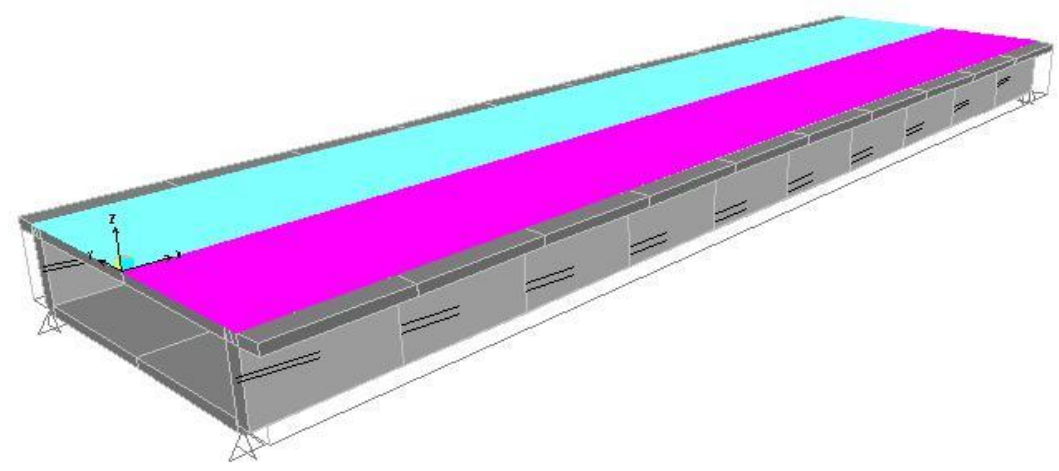

Fig6.2. Modeling of box girder bridge

The tendon profile considered for the design of post tensioned box girder bridge is parabolic and mathematical model is shown in Figure 6.3

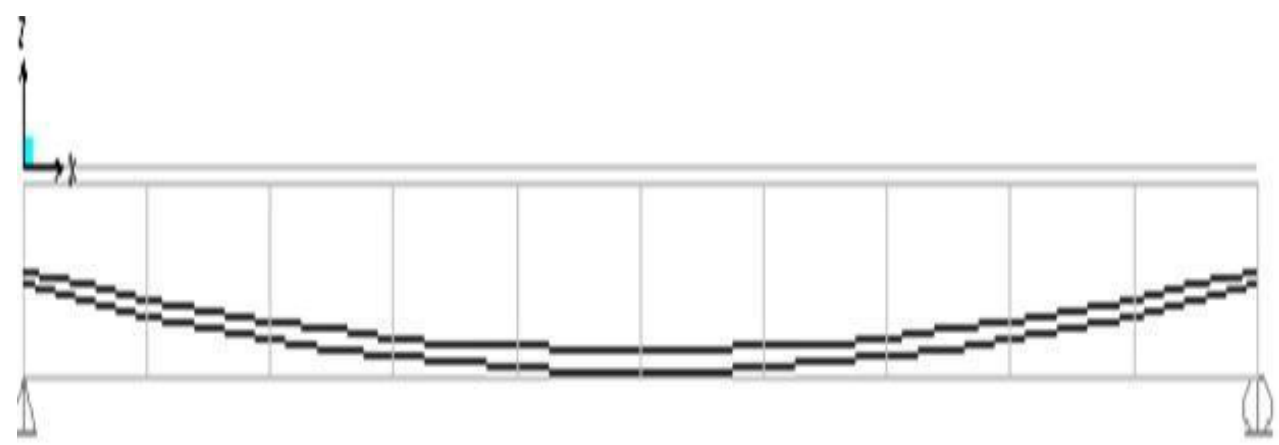

Fig6.3. Tendon profile

\subsection{Validation of Results}

The bending moment, shear force and deflection results are obtained by using SAP2000. The bending moment and shear force are obtained by considering different loading conditions consisting of dead load, super imposed dead load and live load. The results are shown below for case 1 . The variation of bending moment and shear force along the length up to mid span is shown in Tables 6.1 and 6.2. 
Phani Kumar.Ch et al.

Table 6.1. Bending moment variation along span (tm)

\begin{tabular}{|c|c|c|c|c|c|c|}
\hline Span $(\mathrm{m})$ & $0 \mathrm{~L}$ & $0.1 \mathrm{~L}$ & $0.2 \mathrm{~L}$ & $0.3 \mathrm{~L}$ & $0.4 \mathrm{~L}$ & $0.5 \mathrm{~L}$ \\
\hline DL & 0 & 526 & 934 & 1226 & 1400 & 1459 \\
\hline LL & 0 & 218 & 381 & 495 & 565 & 588 \\
\hline SIDL & 0 & 62 & 110 & 145 & 165 & 172 \\
\hline Total & 0 & 806 & 1425 & 1866 & 2130 & 2219 \\
\hline
\end{tabular}

Table 6.2. Shear variation along span $(k N)$

\begin{tabular}{|c|c|c|c|c|c|c|}
\hline Span $(\mathrm{m})$ & $0 \mathrm{~L}$ & $0.1 \mathrm{~L}$ & $0.2 \mathrm{~L}$ & $0.3 \mathrm{~L}$ & $0.4 \mathrm{~L}$ & $0.5 \mathrm{~L}$ \\
\hline DL & 194 & 156 & 117 & 78 & 39 & 0 \\
\hline LL & 80 & 72 & 57 & 41 & 23 & 0 \\
\hline SIDL & 23 & 18 & 14 & 9 & 5 & 0 \\
\hline Total & 297 & 246 & 188 & 128 & 67 & 0 \\
\hline
\end{tabular}

Moment due to DL+SIDL $\left(\mathrm{M}_{\mathrm{g}}\right)=1631 \mathrm{tm}$

Total Maximum moment $\left(\mathrm{M}_{\mathrm{t}}\right)=2219 \mathrm{tm}$

\section{Initial Stresses:}

$\mathrm{f}_{\mathrm{ck}}=50 \mathrm{MPa}$

$\mathrm{fci}=40 \mathrm{MPa}$

$\mathrm{fct}=20 \mathrm{MPa}$

$\mathrm{f}_{\mathrm{cw}}=16.5 \mathrm{MPa}$

$\mathrm{ftt}=2 \mathrm{MPa}$

$\mathrm{f}_{\mathrm{tw}}=0 \mathrm{MPa}$

$\mathrm{fbr}=16 \mathrm{MPa}$

Loss ratio $=0.8$

The variation of prestress force, eccentricity and number of cables with respect to span to depth ratios are summarized in Table6.3

Table 6.3. Calculation of prestress force and eccentricity

\begin{tabular}{|c|c|c|c|c|c|}
\hline $\mathrm{L} / \mathrm{d}$ & 15 & 16 & 17 & 18 & 19 \\
\hline $\mathrm{f}_{\text {sup }}(\mathrm{MPa})$ & 1.57 & 1.59 & 1.6 & 1.62 & 1.64 \\
\hline $\mathrm{f}_{\text {inf }}(\mathrm{MPa})$ & 0.81 & 0.78 & 0.76 & 0.73 & 0.7 \\
\hline Prestressing Force P $(\mathrm{kN})$ & 5428 & 5370 & 5309 & 5251 & 5194 \\
\hline $\mathrm{e}(\mathrm{mm})$ & 850 & 800 & 750 & 700 & 650 \\
\hline
\end{tabular}

The following checks are performed for the above mentioned case1.

\section{Check for Section Modulus:}

Required section modulus $Z_{\text {req }}=571 \times 10^{6} \mathrm{~mm}^{3}$

Provided section modulus $Z_{\text {pro }}=341 \times 10^{8} \mathrm{~mm}^{3}$

$\mathrm{Z}_{\text {pro }}>\mathrm{Z}_{\text {req }}$, Hence the section provided is adequate.

\section{Check for Stresses:}

At transfer stage

Stress at top $=1.52 \mathrm{MPa}<\mathrm{f}_{\mathrm{ct}}$

Stress at bottom $=0.87 \mathrm{MPa}<\mathrm{f}_{\mathrm{tt}}$

At working stage

Stress at top $=1.4 \mathrm{MPa}<\mathrm{f}_{\mathrm{cw}}$

Stress at bottom $=0.48 \mathrm{MPa}$ (As per IS1343:1980 there is no tensile stress) 
All the stresses at top and bottom fibers at transfer and service loads are well within the permissible limits.

\section{Check for Flexural Strength:}

For the centre of span section

According to IRC: $18-2000$,

$\mathrm{Mu}=1.5 \mathrm{M}(\mathrm{G})+2 \mathrm{M}(\mathrm{SG})+2.5 \mathrm{M}(\mathrm{Q})$

$\mathrm{Mu}=40025 \mathrm{kNm}$

The ultimate flexural strength is calculated as follows

Failure by Yielding of Steel

$\mathrm{Mu}=0.9 \mathrm{~d}_{\mathrm{b}} \mathrm{A}_{\mathrm{p}} \mathrm{f}_{\mathrm{p}}$

$\mathrm{Mu}=118244 \mathrm{kNm}$

Failure by Crushing of Concrete

$\mathrm{Mu}=0.176 \mathrm{~b}_{\mathrm{w}} \mathrm{d}^{2} \mathrm{f}_{\mathrm{ck}}+(2 / 3) 0.8\left(\mathrm{~b}-\mathrm{b}_{\mathrm{w}}\right)\left(\mathrm{d}-0.5 \mathrm{D}_{\mathrm{f}}\right) \mathrm{D}_{\mathrm{f}} \mathrm{f}_{\mathrm{ck}}$

$\mathrm{Mu}=234556 \mathrm{kNm}$

The ultimate flexural strength $\mathrm{Mu}=118244>40025 \mathrm{kNm}$, Hence safe.

\section{Deflection Check:}

Table 6.4. Check for deflection

\begin{tabular}{|c|c|c|c|c|c|}
\hline Span/Depth & Prestressing Force $(\mathrm{kN})$ & Eccentricity $(\mathrm{mm})$ & \multicolumn{3}{|c|}{ Deflection $(\mathrm{mm})$} \\
\hline & & & DL+SIDL & DL+SIDL+PRE & DL+LL+PRE+SIDL \\
\cline { 4 - 6 } & 5428 & 850 & 14 & 11 & 18 \\
\hline
\end{tabular}

Maximum permissible deflection according to IS: 1343-1980, Deflection due to self weight + prestress + live load $=\operatorname{span} / 350$ or $20 \mathrm{~mm}$, whichever is less Permissible deflection $=$ minimum of $(86$ or 20$)=20 \mathrm{~mm}>18 \mathrm{~mm}$ Hence safe.

\subsection{Design of Reinforcement in Box Girder Bridge}

\section{Design of End Block}

$\mathrm{P}=5428 \mathrm{kN}$

$\mathrm{b}_{\mathrm{w}}=350 \mathrm{~mm}$

$\mathrm{d}=1800 \mathrm{~mm}$

Assume $200 \mathrm{~mm}$ wide and $200 \mathrm{~mm}$ deep distribution plate, located concentrically at center.

$\mathrm{Y}_{\mathrm{p} o} / \mathrm{y}_{\mathrm{o}}=0.57$

As per IRC18:2000, from table $8 . \mathrm{F}_{\mathrm{bs}} / \mathrm{P}_{\mathrm{k}}=0.149$

$\mathrm{F}_{\mathrm{bst}}=404 \mathrm{kN}$

$\mathrm{A}_{\mathrm{st}}=1119 \mathrm{~mm}^{2}$

Provide $12 \mathrm{~mm}$ diameter bars @ $100 \mathrm{~mm} \mathrm{c} / \mathrm{c}$ in horizontal direction and in vertical direction also same reinforcement provided up to $750 \mathrm{~mm}$ in longitudinal direction and same reinforcement to other web also.

\section{Side Face Reinforcement}

Ast $=315 \mathrm{~mm}^{2}$

Provide 6-12 mm diameter on each face of web.

\section{Design of Deck Slab}

Bending moment $=2219 \mathrm{kNm}$

Depth required $=201 \mathrm{~mm}$

Depth provided $=250 \mathrm{~mm}$ safe. 
Phani Kumar.Ch et al.

\section{Main Reinforcement}

Ast $=4256 \mathrm{~mm}^{2}$

Providing $16 \mathrm{~mm}$ diameter bars $100 \mathrm{~mm} \mathrm{c/c}$

\section{Design of Transverse Reinforcement}

$\mathrm{M}=0.3 \mathrm{ML}+0.2(\mathrm{MDL}+\mathrm{MSIDL}) \mathrm{M}=503 \mathrm{kNm}$

Ast $=1235 \mathrm{~mm}^{2}$

Providing 12 mm diameter bars @ 160 mm c/c

The detailing of side face reinforcement as shown in Figure 6.4 and cross sectional detailing as shown in Figure .6.5

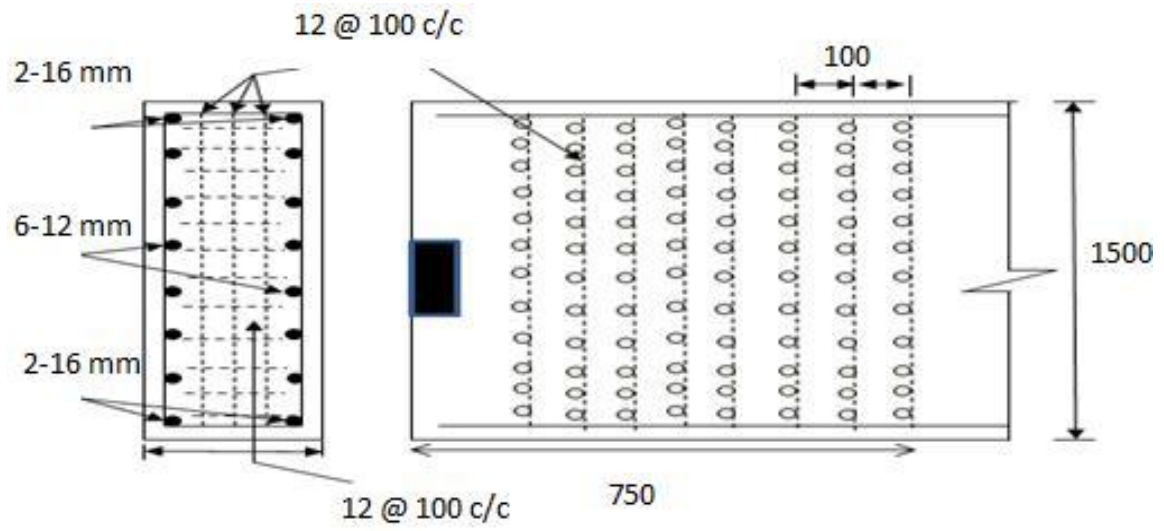

Figure6.4. Side face reinforcement detailing

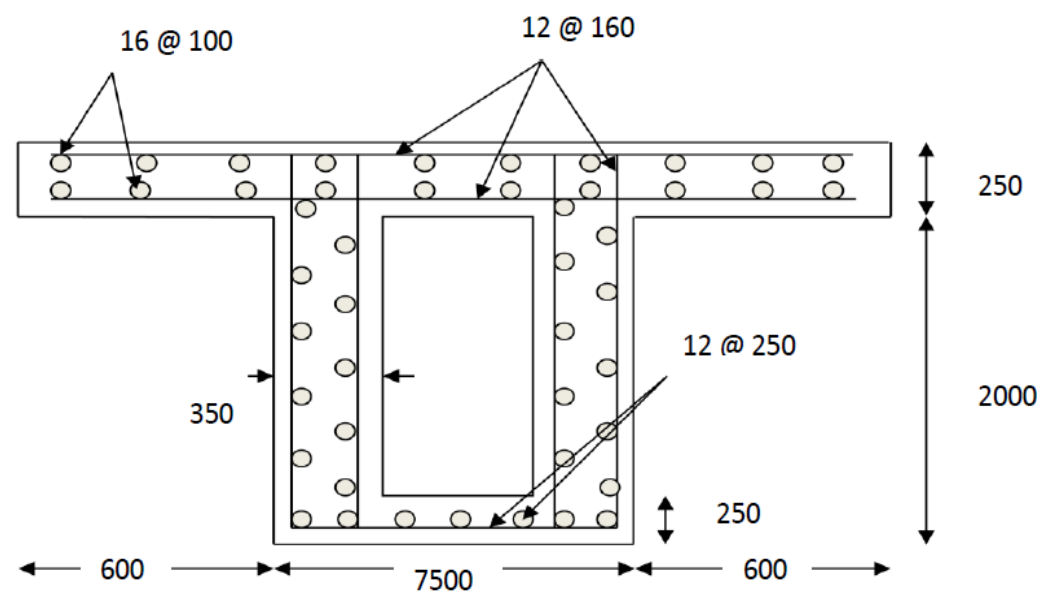

Figure6.5. Cross sectional view (all dimensions are in $\mathrm{mm}$ )

\subsection{Comparison of Results for Various Span to Depth Ratio}

The comparison of prestress force, deflection and stresses values are obtained for various span/depth ratios for box girder bridge as shown in Table 6.5.

Table6.5. Comparison of prestress force and deflection for various span to depth ratio

\begin{tabular}{|c|c|c|c|c|c|}
\hline \multirow{2}{*}{ Span/Depth } & Prestressing Force & Eccentricity & \multicolumn{3}{|c|}{ Deflection (mm) } \\
\cline { 4 - 6 } & $(\mathrm{kN})$ & $(\mathrm{mm})$ & DL+SIDL & DL+SIDL+PRE & DL+LL+PRE+SIDL \\
\hline 15 & 5428 & 850 & 14 & 11 & 18 \\
\hline 16 & 5370 & 800 & 16 & 12 & 20 \\
\hline 17 & 5309 & 750 & 17 & 13 & 23 \\
\hline 18 & 5251 & 700 & 19 & 16 & 26 \\
\hline 19 & 5194 & 650 & 22 & 18 & 29 \\
\hline
\end{tabular}

The comparison of stresses at transfer and working stage for various span to depth ratios for box girder bridge as shown in Table 6.6. 
Table 6.6. Comparison of stresses for various span/ depth ratio

\begin{tabular}{|c|c|c|c|c|c|c|}
\hline Span/Depth & 15 & 16 & 17 & 18 & 19 & units \\
\hline & & \multicolumn{2}{|c|}{ At the Transfer Stage } & & & \\
\hline Stress at Top & 1.52 & 1.51 & 1.5 & 1.49 & 1.48 & Mpa \\
\hline \multirow[t]{2}{*}{ Stress at Bottom } & 0.87 & 0.87 & 0.87 & 0.87 & 0.88 & Mpa \\
\hline & & \multicolumn{2}{|c|}{ At the Working Stage } & & & \\
\hline Stress at Top & 1.41 & 0.43 & 0.43 & 0.42 & 0.41 & Mpa \\
\hline Stress at Bottom & 0.48 & -0.48 & -0.47 & -0.46 & -0.45 & $\mathrm{Mpa}$ \\
\hline
\end{tabular}

\section{Conclusions}

From the analysis and design of post tensioned box girder bridge for various span to depth ratios the following observations are made.

- The various span to depth ratio are taken for the analysis of box girder bridges, and for all the cases, deflection and stresses are within the permissible limits.

- As the depth of box girder decreases, the prestressing force decreases and no of cables decreases. Because of prestressing, more strength of concrete is utilized and also well governs serviceability.

- New code (IRC:112) requires increased cover for pre tensioned strands as well as post tensioned ducts, which will lead to increased thickness of webs and deck slab / soffit slabs for PSC girders / PSC box girder bridges.

- For the same cross section and same applied moment, steel difference is quite noticeable compare to WSM, LSM consumes less steel than WSM and its better to change grade of steel rather increasing grade of concrete for more \%p steel difference.

\section{REFERENCES}

[1] Barr, P.J. (2008). "Comparison of prestress losses for a prestress concrete bridge made with high performance concrete", J. Bridge Eng., ASCE, 13 (5), 468-475.

[2] Byung Hwan Oh, In Hwan Yang (2001). "Realistic long term prediction of prestress forces in psc box girder bridges", J. Structural Eng., ASCE, 127 (9), 1109-1116.

[3] Chang-Su Shim, Pil-Goo Lee, Sung-Pil Chang (2001). "Design of shear connection in composite steel and concrete bridges with precast decks", J. Bridge Eng., ASCE, 15 (3), 725-733.

[4] Dereck J. Hodson, Paul J. Barr, and Marvin W. Halling (2012). "Live-Load Analysis of Posttensioned Box-Girder Bridges", J. Bridge Eng., ASCE, 17(4), 644-651.

[5] Gonzalo R., Angel, C. A., Gonzalo R. and Juan R.C. (2000). "Externally prestressed high strength concrete viaduct", J. Bridge Eng., ASCE, 26 (4), 337-345.

[6] IRC: 18.(2000). Design criteria for prestressed concrete road bridges (post tensioned concrete), IRC, New Delhi, India.

[7] IRC: 6. (2010). Loads and stresses, IRC, New Delhi, India.

[8] IRC:112. (2011). Code of practice for concrete bridges, IRC, New Delhi, India.

[9] IS1343.(1980). Indian Standard code of practice for prestressed concrete (First Revision), BIS, New Delhi,India.

[10] Jarret Kasan, s. m., Kent, A. H. (2011). "Redevelopment of prestressing force in severed prestressed strands", J. Bridge Eng., ASCE,16 (3), 431-437.

[11] John B. Kennedy and Mohamed H. Soliman (1987). "Temperature distribution in composite bridges" J. Structural Eng., ASCE, 113 (3), 475-482.

[12] Krishna Raju, N. (1995). Prestressed Concrete, Tata McGraw- Hill Publishing company Limited, New Delhi.

[13] Leo E. Rodriguez, Paul J. Barr, Marv W. Halling (2013). "Temperature effects on a box girder, integral abutment bridge", journal of performance of constructed facilities, ASCE, 16(7), 548553.

[14] Raina, V.K. (1994). Concrete Bridge Practice-Analysis, Design and Economics, McGraw- Hill Publishing Company Limited, New Delhi. 
[15] S. Maleki (2002). "Effect of deck and support stiffness on seismic response of slab girder bridges", Engineering Structures, 24, 219-226.

[16] Vikash Khatri, Pramod Kumar Singh and P.R.Maiti (2012). "Comparative study of prestressed steel concrete composite bridge of different span length and girder spacing", International Journal of Modern Engineering Research, 2(5), 3917-3922.

\section{AUTHOR's BIOGRAPHY}

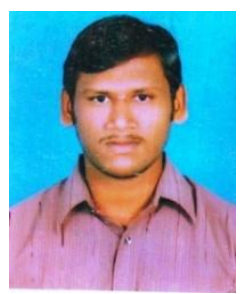

Phani Kumar.Ch, got bachelor of technology in civil engineering from JNTUKakinada University. I did the project on "Analysis \& Design Of Prestressed Box Girder Bridge By Irc-112-2011" in M.Tech Structural engineering with my guide D.aditya sai kumar at Mandava nstitute of engineering and technology, jaggaipeta, Andhra Pradesh.

S.V.V.K.Babu, was born in Machilipatnam, India, in 1991. He received the B.Tech. degree in civil engineering from the University of JNTU KAKINADA, Andhra Pradesh in 2013, and the M.Tech. degree in structural engineering from the University of JNTU KAKINADA in 2015. In 2015, he joined as a Assistant Professor in the Department of Civil Engineering, College of Sri Vasavi Institute of Engineering \& Technology, Nandamuru, Andhra Pradesh. 